\section{Sexuality in Dugesia tigrina (syn. Planaria maculata)}

INDIVIDUALS of the striped variety of Dugesia tigrina collected in the summer of 1935 in the pond behind the Episcopal Church, Falmouth, Mass., have been maintained in the laboratory in finger bowls containing tap water and have been fed beef liver twice or three times a week. During their seven-year stay in the laboratory they have produced egg capsules annually.

In the spring of 1941 the egg capsules deposited by the members of the original 1935 stock were isolated. The worms $\left(F_{1}\right)$ hatching from them were raised under the same conditions as the parents. During the current spring (1942), these animals $\left(F_{1}\right)$ produced cocoons from which viable worms $\left(F_{2}\right)$ emerged.

Hyman ${ }^{1}$ presents the theory that individuals of $D$. tigrina living in quiet water remain asexual and those subjected to a strong current or violent waves become sexual, producing many cocoons ${ }^{1}$.

Neither the $F_{1}$ nor the $F_{2}$ planarians have ever been exposed to any strong current, and their parents and grandparents have lived a quiet, sheltered life for six and seven years respectively.

The data are not compatible with the theory that "moving water is the essential environmental factor in the development of sexuality in D. tigrina". This hypothesis could only be tenable were we to concede that the $F_{1}$ and $F_{2}$ animals become sexual because their ancestors at one time were exposed to moving water. This, the present available facts do not justify. E. D. Goldsmith.

Department of Biology,

College of the City of New York

and Washington Square College,

New York University.

' Hyman, L. H., Trans. Amer. Micro. Soc., 58, 264 (1939).

\section{The Public Schools in Great Britain}

THE recent appointment of a Committee on Public Schools by the President of the Board of Education has stimulated much discussion on the function of the public schools. The main object of this Committee is "to consider means whereby the association between the Public Schools and the general educa. tional system of the country could be developed and extended". The Committee's terms of reference imply only a modification of the existing system. It is for this reason that we issue this statement raising the whole question of the existence of the public schools.

The constitutions of the schools included in the Public Schools Year Book vary considerably. In this document we use the term 'public school' to denote those schools which do not receive grants from the Treasury and which are maintained solely by fees and endowments.

Britain is the only great industrial country where wealth systematically buys a different type of education for its offspring; where education sets a different aim for the wealthy than for those less well off. We thus preserve a system in striking contrast to those of the U.S.A. and U.S.S.R., and of those smaller democracies such as the Scandinavian, to whose social institutions we look with admiration.

The system of public school education is undemocratic. It segregates those children who, by in. heritance, proceed to leading positions in industry, politics. the civil services, the armed forces, and by its training strengthens their social privileges. It is socially injurious, since it divorces this section of our people from the rest, from the life of the main part of the community, especially from all those engaged in the productive processes and manual and technical labour. Men brought up in the public school tradition are out of touch with modern social realities and often incapable of grasping modern social problems.

The prospect of endowing these schocls with Treasury grants is usually linked with a proposal to admit into these schools a limited number of the more gifted members of the poorer sections of society. This proposal is born as much from the financial crisis of the public schools as from an awareness of their social responsibilities. If it were adopted, the main results would be :

(a) a direct subsidy given by the taxpayer to the schools of the wealthy;

(b) the psychological dislocation of the gifted poor boys, who would thus be in the position of poor relation in the family of the rich;

(c) the stultification of the gifts of these hostages, since in this atmosphere they would lose contact with the life and problems of the mass of the people;

(d) the intellectual impoverishment of the Stateaided secondary schools which would thus lose their most gifted pupils.

However much the study of the natural and social sciences is cultivated in the public schools, the divorce between this type of education and life cannot be overcome. Science under these social conditions tends to become an esoteric cult, isolated from social purpose. If non-scientific subjects are adapted to social ends, the public schools tend to develop into institutions for the training of 'leaders', that is, into political academies for the firmer estab. lishment of the dominance of a class. The type of social conscience thus engendered, and expressing itself in this sort of reform, is undemocratic and reactionary.

Any botching and patching of the existing public school system will necessarily tend, whether or not by intent, to perpetuate present evils and inequality. It is true that some public schools possess, at present, advantages from a technical-pedagogical point of view over State-aided secondary schools. But this is no reason for prolonging their existence in their present form. Let us see their educational methods, their organization and their personnel applied to the service of a wider community than the wealthy.

We do not ignore the fact that State-aided secondary education stands in need of considerable reform. Much adjustment is needed in the matter of school government, of curricula, of social status. Once the dichotomy in our secondary education is overcome a concerted drive for reforms in these fields car be made, undistracted by considerations of social prestige and privilege.

We call, therefore, for the full incorporation of the public schools into a unified, State-aided system of secondary education as a step towards democracy in our educational system and towards greater health in our national life.

J: D. Bernal, P. G. H. Boswell, S. Brodetsky, J. Chadwick, W. E. Le Gros Clark, F. A. E. Crew, C. Lovatt Evans, B. Farrington, C. B. Fawcett, P. Sargant Florence, P. F. Frankland, Lancelot Hogben, JULiaN HUXLEx, R. K. Kelsall, R. D. LaUrie, Joseph Needham, R. Pascal, J. A. Ryle, F. Soddy, H. G. Stead, Geo. Thomson, F. F. Weiss, F. Wood-Jones. 